\title{
Engellilere Yönelik Yerel Sosyal Hizmetlerde Belediyelerin Yeri: Malatya Büyükşehir Belediyesi
}

\author{
The Role of Municipalities in Local Social Work forthe Disabled: The Metropolitan \\ Municipality of Malatya
}

\author{
Sami KALAYCI* \\ Aziz AKIN** \\ $\ddot{O} Z$
}

20. yüzyılın ikinci yarısından itibaren engellilere yönelik tıbbi bakım hizmetleri yanındaçeşitli destek ve koruma hizmetleri de sunulmaya başlanmıştır. Ancak toplum hayatında engelli bireylerin kendi varlıkların gösterebilme konusunda uzunca bir dönem geri planda kalmıștır. Bu durum engellilere yönelik politika ve hizmetlerde merkezi idare dışındaki diğer kurumların görev ve sorumlulukları çok fazla yüklenememesinden kaynaklı olduğu söylenebilir. Fakat bu olumsuz olgu yerel sosyal politikalar konusunda belediyelere görev ve sorumluluklar verilmesiyle birlikte değişim göstermeye başlamıştır. Özellikle 2000'li ylllardan itibaren yerel yönetim alanında yapılan reformlarla engellilere yönelik yerel nitelikli hizmetlerde belediyelere bazı yetki ve görevler verilmistir. Böylece engellilere sunulan yerel hizmet ve politika konusunda merkezi yönetimin yanında belediyeler de temel aktör olarak yerini almaya başlamıştır. Reform döneminde 5216 sayll Büyükşehir Belediye Yasası, 5393 sayll Belediye Yasası ile 2012 yllında çıkarllan 6360 sayll yasa engelli alanında belediyelere yönelik emredici hükümler ile görevler yükleyerek çeşitli haklar ile hizmetleri ortaya koymuştur. Bu bağlamda belediyeler kendi imkânları dâhilinde hizmetlerin niteliğinden mekânların kullanıma kadar farkl hizmetleri engellilerin kullanimina sunmaya ve toplum hayatına uyum konusunda destek olmaya çalışmıştır. Dolaylsıyla çalı̧̧mada engelli bireylere yönelik belediyelere verilen görev ve sorumluluklar ile hizmet ve uygulamalar Malatya Büyükşehir Belediyesi örneği üzerinden ele alınmıştır. Böylece yerel alanda belediyelerin engellilere yönelik sunduğu iyi hizmet uygulamaların ortaya koymak, olası eksiklikleri tespit etmek ve ileride yapılacak hizmetlere yol göstermek amaçlanmıştır.

\section{ANAHTAR KELIMELER \\ Engelli, Engelli Hizmetleri, Belediye, Sosyal Hizmet, Yerel Yönetimler ABSTRACT}

From the second mid of the 20th century on, various support and services have been offered to the disabled people as well as medical care services. However, in social life, they have fallen back when it comes to prove and establish themselves in society. We might say that there as on for the case is due to the fact that institutions and organizations out of centrel government do not feel responsible enough for the policies and services for the disabled. However, this negative case started to change soon after municipalities were charged with duties and responsibilities regarding local social policies. Especially, during the years following 2000 when some innovative reforms were accepted in local government, the municipalities were given some duties and responsibilities regarding qualified local services for the disabled. Therefore, as well as central government, municipalities also started to play a critical role in duties and responsibilities for the disabled individuals. Following these changes and newly added laws like The Metropolitan Municipality Law numbered 5216. The Municipality Law numbered 5393 and the law 6360 enacted in 2012, the municipalities were given further duties and responsibilities for the disabled. In this sense, the municipalities, with their own means, have not only tried to support the disabled individuals with more quality services and the use of buildings, but they have also helped them accommodate themselves to the society. In our study, duties, responsibilities and services were illustrated by the example of the metropolitan municipality of Malatya. To do so, we aimed to clarify good services of the municipalities for the disabled, to find out the problems within current services and study potential services in the future.

KEYWORDS

The Disabled, Services for the Disabled, Municipality, Social Work, Local Governments

\begin{tabular}{|c|c|c|}
\hline \multicolumn{2}{|r|}{$\begin{array}{c}\text { Makale Geliş Tarihi / SubmissionDate } \\
15.10 .2019\end{array}$} & $\begin{array}{c}\text { Makale Kabul Tarihi / Date of Acceptance } \\
12.11 .2019\end{array}$ \\
\hline Attf & $\begin{array}{l}\text { Kalaycı, S. ve Akin, A. (2019). Engell } \\
\text { Belediyesi. SelçukÜniversitesi Sosyal }\end{array}$ & $\begin{array}{l}\text { al Hizmetlerde Belediyelerin Yeri: Malatya Büyükşehir } \\
\text { ulu Dergisi, } 22 \text { (2), 663-674. }\end{array}$ \\
\hline
\end{tabular}

\footnotetext{
* Dr. Öğr. Üyesi, Şırnak Üniversitesi, İktisadi ve İdari Bilimler Fakültesi, Sosyal Hizmet Bölümü, samiklyc@ gmail.com, ORCID:0000-0002-09819595

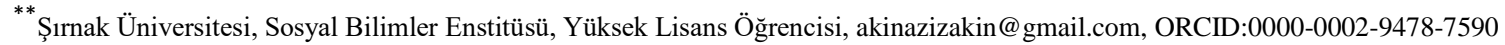




\section{GİRIŞ}

1950'li yıllardan itibaren engelli bireylerin hakları konusunda fikir ve söylemlerin öne çıktığı, ihtiyaçlarının karşılanmasında faaliyetlerin daha da arttığı bir süreç ortaya çıkmıştır. İkinci Dünya Savaşı'na bağlı çeşitli nedenlerden engelli sayısında artışların olması, bu alandaki sağlık politikalarının yaygınlaşarak önem kazanmasına neden olmuştur. Ancak, bu politikaların 70'li yıllardan sonra yetersizleşmesi engellilere yönelik daha kapsamlı yeni politika ve aktörlere ihtiyacı doğurmuştur. Bu bağlamda Amerika, İngiltere, Almanya gibi batılı ülkelerde sivil toplum kuruluşları başta olmak üzere çeşitli kurumlar eliyle çalışmalar yürütülmüştür (Arıkan, 2001: 59-60).

1975 yılı sonrası Avrupa'da engelli bireyler konusunda çalışmaların hızlandığı bir dönem olmuştur. Bu çerçevede 1975 yılında yayımlanan "Engelli Hakları Bildirgesi" ile engellilerin diğer vatandaşlar ile eşit haklara sahip oldukları belirtilmiş ve 1981 yılı Uluslararası Engelliler Y1lı olarak kabul edilmiştir. Bir yıl sonra 1982 yılında "Engelliler İçin Dünya Eylem Planı" kabul edilmiştir. Daha sonra 1986 yılında Avrupa Birliği’nde "Engellilerin İstihdamına Yönelik Konsey Tavsiye Kararı" alınarak 1996 yılında "Engelliler için Fırsat Eşitliğì" hakkında karar alınmıştır. 2000'li yıllarda ise gelecek yılları kapsayan "Avrupa Konseyi ayrımcılıkla mücadele konusunda 2001-2006 yıllarını kapsayan topluluk eylem programı oluşturulması kararı" alınmıştır. Ayrıca Avrupa Birliği 2000 yılında “Avrupa Birliği Temel Haklar Şartı”nı kabul ederek engellilik konusunda önemli bir adım daha atmıştır (www.ailevecalisma.gov.tr, 2019). Dolayısıyla engellilere yönelik ulusal ve uluslararası çeşitli politikalarla; engelli bireylerin sağlık, ekonomi, sosyal ve kültürel alanlardaki durum ve şartlarının iyileştirilmesi bakımından önemli mesafeler katedilmiştir (Genç ve Çat, 2013: 366).

Engellilik kavramı çok boyutlu ve tartı̧̧malı konulardan birisi olmuştur. Araştırmacılar; geçmişten günümüze kadar sağlık ve sosyal alanlarda, sosyal ve fiziksel engellerin engelliliğe dair rol ve etkilerini tespit etmeye çalışmıştır. Bu dönemler, bireysel tıbbi modelden toplum tarafından insanların engelli konuma düşürüldüğü sosyal modele geçiş olarak nitelendirilmiştir (WHO, 2011: 3-4). Engellilik kavramına ilk zamanlarda daha çok fiziksel bir engel olarak bakılırken; daha sonra toplumdan dışlanma, ötekileştirme gibi sorunlar üzerinde durulmuştur. Dolayısıyla engellilik kavramı; bireyin psikolojik, sosyolojik ve biyolojik olmak üzere üç temel alandaki eksiklik veya aksamaları olarak şekil almıştır.

"Engellilik” kavramı, Dünya Sağlık Örgütü tarafından; kişinin demografik veya toplumsal gerekliliklerine göre normal olan faaliyetlerde bulunamama ya da bulunma yeteneğini kisitlayan veya ortadan kaldıran dezavantajlı bir durum olarak tanımlamıştır. Bu kavramla eş anlamda kullanılan "sakatlık" kavramı ise sağlık yönünden noksanlık şeklinde ifade edilmiştir. Ayrıca diğer bir kavram olan "özürlülük" de bir iş yapma yeteneğinin kaybolması veya eksilmesi olarak tanımlanmıştır. Dolayısıyla genel anlamda bakıldığı zaman farklı nedenlerden kaynaklı olarak engellilik durumu zihinsel, bedensel ve süreğen olmak üzere farklı türlerde ortaya konmuştur (Dünya Engelliler Vakfi, 2018).

Birleşmiş Miletler Genel Kurulu'nda kabul edilip 2008 yılında yürürlüğe konulan Engelli Haklarına İlişkin Sözleşme (Convention on the Rights of Persons with Disabilities) engelli alanında uluslararası bir belge niteliğindedir. Sözleşmenin birinci maddesinde, sözleşmenin amacının engelli bireylerin bütün insan haklarına ve temel özgürlüklere tam ve eşit biçimde sahip olmalarını sağlamak olduğu belirtilmiştir. Maddenin devamında engelli bireyi, diğer insanlarla eşit temelde toplumsal yaşama tam ve etkin katılımlarını kısıtlayan davranışsal ve çevresel engeller ile etkileşim içerisinde olan uzun süreli fiziksel, zihinsel, düşünsel ya da duyusal bozukluklara sahip kişiler olarak tanımlamışırı. Dolayısıyla engellilik, bireyin kendi bir sorunu olması ötesinde bu kişilerin toplumsal hayata katılmalarını engelleyen davranışsal ve çevresel bariyerlerle ilgili bir olgu olarak kabul edilmiştir. Bu çerçevede engelliler için sosyal ilişkilerden kültürel ve toplumsal faaliyetlere, temel hizmetlere erişimden yakın çevre ve iktisadi sahada yer almaya kadar engellenmek ikinci bir engel durumu olarak görülmektedir (Genç, 2015: 67). Bu nedenle engelli hizmetleri noktasında yapılan tüm çalışmalar ile bunların şekil almasında rol oynayan aktörler önemli olmuştur.

Engellilere yönelik sunulan hizmet ve çalışmalarda başta merkezi idare olmak üzere belediyeler, sivil toplum kuruluşları, özel sektör girişimleri ve gönüllü kuruluş veya girişimler tarafindan çeşitli çalışmalar günümüzde yürütülmektedir. Bu çalışma ve faaliyetlerin yürütülmesinde 1982 Anayasası en temel ve birincil dayanak olmuştur. Bu bağlamda Anayasa'nın 10., 50. ve 61. maddeleri engelli bireylere yönelik temel düzenlemeleri içermiştir. Bu çerçevede engellilere yönelik çalışmaları yürütecek kurum ve kuruluşlara yönelik hazırlanan çeşitli yasal düzenlemelerle de ilgili birim, kuruluş veya girişimler faaliyetlerini yürütmüştür. Bu kuruluşların içerisinde merkezi yönetimin yerel alandaki engellilere yönelik hizmetlerde temel destekleyicisi olan kurumlardan birisi de belediyelerdir. Bu bakımdan yerel alanda halka en yakın 
yönetim kademesi olan belediyeler, hem mevzuat kaynaklı hem de yerelde yaşayanların talep ve beklentileri doğrultusunda engellilere yönelik hizmetler yapmaya çalışmaktadırlar. Dolayısıyla engelli hizmetlerinde henüz istenilen düzeye erişemeseler de yaptıkları çeşitli faaliyet ve düzenlemelerle belediyeler, engelli bireylerin toplum içindeki varlıklarına dikkat çekmiştir.

\section{ENGELLILIIĞİN TARIHII SÜRECI}

Engelli tarihi, insanlık kadar eski olsa da toplumların kültür ve inançlarından kaynaklı engelliye bakış açıları farklı olmuş ve bu durum zamanla değişiklik göstermiştir. Dolayısıyla engelliler tepkilere, dışlanmaya veya acınmaya tarih boyunca maruz kalmıştır. Bu davranışların sebebiniBartan 3 temel tepkinin varlığına dayandırmıştır. Bunlardan ilki, toplumun korunması açısından "tehdit edici" unsur olarak görülmeleri, ikincisi; toplum için ayak bağı yani "yük" olmaları ve son olarak da engelli bireylerin toplum tarafindan "aciz" olarak nitelenmiş olmasıdır. Dolayısıyla engellilere yönelik "korumacı ve acınası" bir bakış açısı ortaya çıkmıştır (Kolat, 2009: 28).

Engellilik ve engelli insanlar ilk medeniyetlerde genel olarak uğursuzluk veya engelli bireyin ebeveynlerinin yaptığı bir hatanın bedeli olarak görülmüştür. Bundan dolayı da engelliyi korumak veya ona yardım etmek tanrıya karşı gelme ve onun tepkisi ile karşı karşıya kalınacağ düş̧üncesinden dolayıengelliler, toplumsal hayattan uzak tutulmaya çalışılmış, ölüme terk edilmiş veya öldürülmüştür. Bu şekilde toplum korunulmuş olup tanrının gazabından da uzaklaşıldığı düşünülmüştür (Öztürk, 2011: 16). Engelli tarihinde, Antik Yunan ve Roma uygarlıkları döneminde engellilik; yapılmış kötülüğün bedeli veya kötü ruhlar, cadılar ve büyü gibi konularla ilişkilendirilmiştir. Antik Çağ döneminde engelliler; aykırı kişiler, marjinaller, toplum tarafından istenilmeyen, hor görülen ve baskı altına alınan gruplar olmuşlardır. Platon ve Aristoteles gibi ünlü filozoflar, mevcut devlet anlayışında engellilerin varlığından rahatsızlık duymuş ve onların toplumda barındırılmasına karşı çıkarak zayıfların, fiziksel ve bilişsel engellilerin ölümünü desteklemişlerdir. Bu dönemde yasalarla da engellilerin yaşantıları kısıtlanmıştır. Örneğin Antik Yunan Sparta Uygarlığında, engelli doğan bebeklerin güneşli tepelere terk edilmesi, bağlanması ve ölüme terk edilmesi kabul edilir bir durum olmuştur (Çetin, 2016: 170-175).

Orta Çağ, genel itibariyle bir önceki dönemin bakış açısıyla aynı izler taşımıştır. Engelli çocukların, şeytanlar veya cadılarca himaye altına alınan, değiştirilen ve cinlerin musallat olduğudüşünülmüştür. Bu bireyler topluma itibar kaybettiren kişiler olarak görülmüşlerdir. Özellikle bu dönemlerde kilise ve rahipler tarafından, engelli bireylerin şeytani gereçlere hizmet ettiği ve öldürülmesi gerektiği belirtilmiştir (Köse, 2014: 66-69). Orta Çağ'dan Sanayi Devrimi’ne kadar geçen süreçte Batı dünyasında engellilere bakışın değişmesine neden olacak Rönesans Hareketleri; Leonardo Da Vinci, William Harvey ve Versailius gibi sanatçı ve bilim insanlarının, insan anatomisi ve fizyolojisi çalışmaları olsa da bu dönemde engellilere yönelik bakış açısı ve uygulamalar değişmemiştir. Sanayi Devrimi'ne doğru yaklaşırken Amerika Kolonileri Dönemi'nde Philip Nelson (engelli bir bireyi eğitme ve onunla iletişim kurma girişimi) ve Jan Amos Komensky (Doğu Avrupa'da sınıf ve statü fark etmeksizin, tüm çocukların eşit şartlarda eğitim görme reformu) gibi düşünürler engelli bakış açısını kırma girişimlerinde bulunsalar da kilisenin tepkileriyle karşılaşmışlardır. 1700'lü yıllardan itibaren ise engelli konusundaki fikirler değişim göstermeye başlamış ve ilk adımlar atılmıştır. Bu dönemde İspanyol Keşiş Ponce de Leon tarafından işaret dilini öğretme, Benjamin Franklin ve Thomas Bond tarafından ise engellilere bakım ve rehabilitasyon hizmeti sunan ilk hastaneyi kurma girişiminde bulunulmuştur. Ayrıca Amerika Birleşik Devletleri, engellilerin hak ve vatandaşlık kazanması konusunda öncü adımlar atmıştır (Çetin, 2016: 179-180).

Sanayi Devrimi yaklaşırken engellilere yönelik başlatılan çalışmalar ve engellilerin yaşama kazandırılma girişimleri sanayi ile beraber artan teknoloji ve üretim faaliyetleri nedeniyle tekrardan duraksama dönemine girmiştir.FakatSanayi Devrimi'yle hızlanan üretim faaliyetleri karşısında engellilerin ailelerine yük olarak görülmesi ve bu dönemde kiliselerin etkisinin azalması; engelliler konusunda devletin koruyucu bir rol alması, tedavi ve bakım hizmetlerini üstlenmesine neden olmuştur (Çarkçı, 2011: 17). Sanayi Devrimi ile artan makineleşme beraberinde endüstriyel kazaları ve mesleki riskleri artırmış ve zarar gören insan sayısındaciddi artışlar yaşanmıştır. Ayrıca savaşlardan kaynaklı artan engelli birey sayısı uluslararası alanda engellilere yönelik düzenlemeleri zorunlu kılmıştır. Çünkü hem iş hayatındaki riskler hem de savaşlara bağlıolarak azalan nüfus ve iş gücü potansiyeli engellilerin yaşama dâhil edilmesinde büyük bir rol oynamıştır (Gökmen, 2007: 1093). Ancak bu tür risk ve olumsuzluklara rağmen engelliler uzunca bir süre dışlanan ve acınılan bireyler olarak görülmüşlerdir.

Birleşmiş Milletler'in "herkes için eşitlik" ilkesine rağmen 20. yüzyılın ortalarına kadar engellilere yönelik hak ve çalışmalar kısıtlı kalmıştır. "Özürlülük” söylemi Birleşmiş Milletler belgelerinde ilk kez 1948 yılında İnsan Hakları Evrensel Bildirgesi'nde dile getirilmiştir. Bedensel engellilere yönelik çalışmalar ise 
1945 yılında başlamış, engelliliği önleme ve rehabilitasyon amacıyla 1950 yılından Cenova Konferansi'nda bu durum dile getirilerek bir komisyon kurulmuş ve engellilere yönelik eğitim, tedavi, rehabilitasyon ve istihdam konularında uluslararası standartların belirlenmesi kararlaştırılmıştır (https://engellilerdostu.com/engelliligin-dunyadaki-tarihsel-gelisimi/). 1960'l1 y1llardan sonra engelli haklarına yönelik Amerika Birleşik Devletleri ve İngiltere'de başlayan, engelliliğin tıbbi yönleri yanında toplumsal yönlerini önemseyen ve "Engelli Hakları Hareketi" ile yürütülen çalışmalar engelli konusundaki modern sosyal politikalardan birisi olmuştur (Çetin, 2017: 100-101). Bu bağlamda uluslararası çeşitli kurum ve kuruluşlar ile ülkeler; engellilerin sosyal, ekonomik ve siyasal yaşamdaki dezavantajlarını gidermek amacıyla farklı politikalar yürütmeye başlayarak engellilerin sorunlarını gidermeye çalışmışlardır.

\section{YERELDEKİ ENGELLİ HIZMETLERINDE BELEDIYYELERİN YERİ}

Belediyelerin engellilere yönelik sunduğu hizmetlerin başlangıcı 19. yüzyıla kadar uzanmıştır. 1850'li yıllardan itibaren Osmanlı Devleti'nde yerel yönetim olarak belediyelerin teşkilatlanmaya başlamasıyla birlikte, yoksullar ile engellilere destek verilmeye başlanmıştır. 1868 tarihli Dersaadet İdare-i Belediye Nizamnamesi, belediye sınırları içerisindeki yoksullara bakma görevini şehremanetine yüklemiş ve Memurîn-i Mülkiye Terakki ve Tekaüd Kararnâmesi gereği babası devlet memuru olup da vefat eden engelli bireylere maaş bağlanmıştır. Benzer şekilde 1877 tarihli Dersaadet Belediye Kanunu ile Vilayet Belediye Kanunu belediyelere kendi bütçelerinden engellilere yardım etme yükümlülüğü getirmiştir. Ayrıca 26.11.1911 tarihli Askerlik Kanunu ile sağır, dilsiz ve âmâ olan engelli bireyler askerlik görevinden muaf tutulmuştur (Balc1, 2013: 85-86).

Tarihi süreç ile birlikte engelli alanında kazanılan deneyimler Cumhuriyet Dönemi ile devam ettirilerek çeşitli şekillerde günümüze kadar gelmiştir. Bu bağlamda dünya üzerinde birçok ülkede olduğu gibi Türkiye'de de sosyal politika alanındaki plan ve programların uygulanmasında merkezi yönetim ile birlikte yerel idareler, özellikle belediyeler önemli çalışmalar yürütmektedir. Yerel yönetim; yerel bir topluluktaki bireylerin ortak gereksinimlerini karşılayan, kamu mal ve hizmetlerini sağlayan ve yerel halkın kendi seçtiği organlarca yönetilen birimlerdir (Tekeli, 1983: 3). "Yerel yönetimler", ulusal sınırlar içerisinde yaşayan insanların yerel nitelikteki ortak gereksinimlerini karşılamak amacıyla kurulmuş anayasal kuruluşlardır. Yerel yönetim anlayışının temelinde yerel demokrasi değerleri bulunmaktadır. $\mathrm{Bu}$ değerler, yereldeki toplulukların kendileriyle ilgili olan yakın konularda özgürce ve demokratik yol ve yöntemlerle kendi kendilerini yönetmelerini öngörmektedir (Genç, 2009: 61). Dolayısıyla yerel yönetimler, özelde ise belediyeler, yerel alandaki sosyal hizmetler noktasında oldukça önemli bir idare şekli olmuştur.

Günümüz toplum hayatında dezavantajlı konumda olan engelli bireylere yönelik en temel yasal dayanak 1982 Anayasası'dır. Anayasa ile engellilerin korunması güvence altına alınmış ve engellilerin korunması anayasal bir hak olarak tanınmıştır. Daha sonrasında çıkarılan yasa, tüzük, yönetmelik gibi çeşitli düzenlemelerle engelli bireylere yönelik kurum ve kuruluşlar ile ilgili çalışmalar ortaya konmuştur.

1982 Anayasası'nın 10. maddesine göre "Herkes, dil, rrk, renk, cinsiyet, siyasi düşünce, felsefi inanç, din, mezhep ve benzeri sebeplerle ayırım gözetilmeksizin kanun önünde eşittir. Çocuklar, yaşlılar, özürlüler, harp ve vazife şehitlerinin dul ve yetimleri ile malul ve gaziler için alınacak tedbirler eşitlik ilkesine aykırı sayılmaz." Buna göre herkes kanun önünde eşit iken engelli gibi dezavantajlı bireylere yönelik yapılan düzenlemeler eşitlik ilkesine aykırılık teşkil etmemektedir. Anayasa'nın bir diğer maddesi olan 50. maddeye göre de "Kimse, yaşına, cinsiyetine ve gücüne uymayan işlerde çalıştırllamaz. Küçükler ve kadınlar ile bedeni ve ruhi yetersizliği olanlar çalışma şartları bakımından özel olarak korunurlar". Ayrıca engelli bireyler ile diğer dezavantajlı gruplara yönelik olarak Anayasa'nın 61. maddesinde:

"Devlet harp ve vazife şehitlerinin dul ve yetimleriyle, malul ve gazileri korur ve toplumda kendilerine yaraşır bir hayat seviyesi sağlar. Devlet, sakatların korunmalarını ve toplum hayatına intibaklarını sağlayıcı tedbirleri alır. Yaşlılar, Devletçe korunur, Yaşlılara Devlet yardımı ve sağlanacak diğer haklar ve kolaylıklar kanunla düzenlenir. Devlet, korunmaya muhtaç çocukların topluma kazandırılması için her türlü tedbiri alır. Bu amaçlarla gerekli teşkilat ve tesisleri kurar veya kurdurur" hükmü getirilmiştir.

Türkiye'de merkezi idarenin 1993 yılında engelli gelir destek programı kapsamında engellilere yönelik başlattığ 1 ilk proje girişimi istenilen sonucu verememiştir. Bu kapsamda Sosyal Hizmetler ve Çocuk Esirgeme Kurumu Genel Müdürlüğü tarafından engellilerin evde bakımı konusunda Ankara, Adana, İzmir ve İstanbul illerinde başlattığı pilot çalışmalar ${ }^{1}$ devam ettirilememiştir (Şensoy ve Karabekir, 2011: 22). Ancak

\footnotetext{
${ }^{1}$ Evde bakım ve gündüzlü hizmeti konusunda Türkiye'deki ilk proje 1993 yılı sonunda başlatılmıştır. Sosyal Hizmetler ve Çocuk Esirgeme Kurumu Genel Müdürlüğü tarafından Ankara, Adana, İzmir ve İstanbul illerinde uygulanmaya konulmuştur. Hem evlerinde tek başına yaşayan yaşlılara
} 
bir yıl sonra 1994 yılında Ankara Büyükşsehir Belediyesi bünyesinde "Yaşlılara Hizmet Merkezi" kurulmuştur. Kurulan bu merkez sayesinde yaşlı bireylere yönelik evde bakım hizmetleri kapsamında çeşitli hizmetler sunulmaya başlanılmıştır. ${ }^{2} 2001$ yılında ise İstanbul Büyükşsehir Belediyesi'ne bağlı İstanbul Sağlık Anonim Şirketi yaşlılara yönelik benzer nitelikte evde sağlık ve destek hizmetleri çalışmalarını yürütmüştür (Danış, 2005: 57). Dolayısıyla yerelde sunulan engelli hizmetlerinde belediyelerin merkezi yönetime verebileceği destekleri gösterme adına 90'lı yıllarda yaşanan bu gelişmeler önemli bir kanıt niteliği taşımışıır.

Türkiye'de yerel yönetimlerin yeniden yapılanma süreci 2004 y1lında başlatılmış ve dünyada yaşanan gelişmeler takip edilerek bu süreç devam ettirilmiştir. Bu çerçevede 2004 y1lında çıkarılan 5216 sayılı Büyükşehir Belediye Kanunu ve 2005 yılında düzenlenen 5393 sayılı Belediye Kanunu ile sosyal hizmet ve yardımlar konusunda belediyelere yetki ve sorumluluklar tanımlanmıştır. Bu nedenle yerel yönetim olarak belediyeler alt yap1, temizlik, çevre düzenlemesi, imar, ulaşım gibi hizmetlerle birlikte çeşitli sosyal hizmet ve yardımları da yapma görevlerini de üstlenmektedir. Dolayısıyla sosyal belediyecilik anlayışı kapsamında yerel yönetimlerin özel gereksinimli bireyler ile riskli alanlar konusunda koruyucu ve iyileştiricisosyal hizmet uygulamaları yapması mevzuat çerçevesinde yasal bir zorunluluk olmuştur (Genç ve Barış, 2015: 109).

1982 Anayasası dışında engellilere yönelik hak ve imkânlar konusunda en kapsamlı yasal düzenleme 2005 y1lında yürürlüğe giren 5378 sayılı Engelliler Hakkında Kanun'dur. Bu yasa ile Türkiye'de engellilere yönelik politikalar ile bu politikaları yürütecek kurum ve kuruluşlar ele alınmıştır. 5378 sayılı yasanın 4 . maddesi gereği engelli alanındaki belirlenecek politikalar ile bu politikaların yürütülmesinde göz önünde tutulması gereken ilkeler şu şekildedir:

- Bireysel özgürlük,
- Fırsat eşitliği,
- Erişilebilirlik,
- İstismarın önlenmesi,

- Aile bütünlüğünün korunmas1,

- Çocuğun üstün yararı,

- Katılımcı kararlar alma,

- Sivil toplumun katılımı,

Hem demokratik katılımın ilk basamağı hem de yereldeki sosyal ihtiyaçların karşılanmasında temel birimlerden biri olan yerel yönetimlerin 5378 sayılı yasa ile diğer mevzuatlar gereği engelli haklarını sağlama ve engelliği sosyal yaşama dâhil etme konusunda yapacakları hizmetler önem arz etmektedir. Dolayısıyla fiziki mekânları engelli lehine düzenlemeden engellilerin ulaşım hakkı, istihdam imkânı ile sosyo-ekonomik yönden güçlenip sosyal hayata katılmalarına kadar yereldeki engelli politikalarının yürütülmesinde belediyelerin çeşitli sorumlulukları önem kazanmıştır (Kesgin, 2014: 2).

Uluslararası belge niteliği taşıyan "Avrupa Kentsel Şartı”nda kente özgü alan ve mekânlarda engelli bireylere ve haklarına yönelik "her kentlinin temel hakkl, kentteki tüm sosyal etkinlik ve olanaklara yaş, ırk, bedensel ve zihinsel kabiliyetlerine bakılmaksızın, kendi özgür iradeleriyle erişim hakkına sahiptir" şeklinde bir düzenlemeye gidilmiştir. ${ }^{3}$ Böylece kentsel alandaki engelli bireylerin hakları ile firsat eşitliğine işaret edilmiştir.

Günümüz Türkiye'sinde engelli nüfusun kente özgü alanlarda yoğunlaşmaya başladığı gözlenmektedir (Kesgin, 2014: 4). Dolayısıyla engelli bireye yönelik her türlü hizmet ve çalışmalarda kent yönetimleri yani belediyeler gün geçtikçe önem kazanmaktadır. Çünkü gün geçtikçe belediyeler yerel alanlardaki sosyal nitelikli sorunların çözümünde önemli bir birim olma yolunda ilerlemektedirler (Kesgin, 2016: 334). Bu bağlamda yerel alanda engelli politikalarının uygulanmasında merkezi yönetim kadar belediyelerin de oldukça önemli görev ve sorumluluk taşıyacakları aşikârdır.

“Avrupa Kentsel Şartı”na göre kentsel alandaki engellilerin en önemli haklarından birisi de erişim hakkıdır. Bu çerçevede engelli bireyin her türlü hizmet ve imkâna erişmesinde eşitliğin sağlanması önemlidir. Bu konuda da yerelde sunulan tüm hizmetlere normal sağlıklı bir vatandaşın ulaştığı gibi engelli bir bireyin de ulaşabilmesinde belediyelerin rolü önemli ve büyük olmaktadır. Dolayısıyla 2000 yılından sonra belediye yasalarında yapılan reformlarda engelli konusunda belediyelere çeşitli görevler yüklenmiştir.

\footnotetext{
yardımcı olmak hem de evde bakım hizmetinde yer alacak ara personelin yetiştirilmesi amacıyla başlatılan bu proje, pilot uygulamalardan istenilen etkili sonuç elde edilemediği için sonlandırılmıştır (Danış, 2005: 57).

${ }^{2}$ Ankara Büyükşehir Belediyesi Sosyal İşler Daire Başkanlığı bünyesinde faaliyet gösteren Yaşlılara Hizmet Merkezi'ne yaşlılar üye olup hizmetlerden faydalanmaktadır. Bu kapsamda 2019 yılı itibariyle 52.537 yaşlı birey hizmetlere ulaşmak için merkeze üye olmuştur (Yaşlı Dostu Belediye, 2019).

${ }^{3} \mathrm{Bu}$ düzenleme daha çok kentte yaşayan engelli nüfusa yönelik bir düzenlemeyi içermektedir. Ancak bu düzenleme, kentli veya kırsal alan şeklinde ayrım yapmak yerine tüm engelli ve dezavantajlı konumdaki bireylere yönelik daha geniş kapsamlı olacak şekilde yeniden ele alınmalıdır.
} 
5393 sayılı Belediye Kanunu'nun 14. maddesindeki "Belediye hizmetleri, vatandaşlara en yakın yerlerde ve en uygun yöntemlerle sunulur. Hizmet sunumunda engelli, yaşlı, düşkün ve dar gelirlilerin durumuna uygun yöntemler uygulanır" hükmü gereğince, hizmetin yerine getirilmesinde engelli bireyler ile diğer dezavantaj1ı konumdaki bireylerin durumlarına göre uygun yöntemin kullanılması belirtilmiştir.

Belediye yasasının 38. maddesinde "Bütçede yoksul ve muhtaçlar için ayrılan ödeneği kullanmak, engellilere yönelik hizmetleri yürütmek ve engelliler merkezini oluşturmak" şeklinde belediye başkanının görevleri arasındadır. Bunun yanında yasanın 60. maddesinde "Dar gelirli, yoksul, muhtaç ve kimsesizler ile engellilere yapılacak sosyal hizmet ve yardımlar" şeklinde belirtilen hüküm gereği engellilere yönelik sunulan sosyal hizmetler ile yardımlar belediye giderleri arasında sayılmıştır. Dolayısıyla belediye tüzel kişiliğini temsil eden belediye başkanın görevleri arasında engellilere yönelik hizmetleri sunmak ve bunlara ilişkin harcamaları da belediye giderlerinden saymak yasal bir zorunluluk olmuştur.

Belediyeler 5393 sayılı yasadan kaynaklı engellilere yönelik hizmetleri yürütmede sivil toplum kuruluşları ile işbirliği yapma imkânına sahiptir. Yasanın 75. maddesinin c bendinde belediyelere engellilere yönelik faaliyet yürüten dernek ve vakıflar ile birlikte çalışabilme fırsatı tanınmıştır. Ayrıca yasanın 77. maddesindeki "Belediye; sağlık, eğitim, spor, çevre, sosyal hizmet ve yardım, kütüphane, park, trafik ve kültür hizmetleriyle yaşlılara, kadınlara, çocuklara, engellilere, yoksul ve düşkünlere yönelik hizmetlerin yapılmasında beldede dayanışma ve katılımı sağlamak, hizmetlerde etkinlik, tasarruf ve verimliliği artırmak amacıyla gönüllü kişilerin katılımına yönelik programlar uygular" hükmü gereği engelli hizmetlerinde belediye çalışmalarına yerel halkın gönüllü katılımını teşvik etme ve sağlama imkânı getirilmiştir. Böylece belediyeler engellilere yönelik yerel çalışmalarda yönetişim ilkesini uygulama firsatına da sahip olmuştur.

2004 yılında yürürlüğe konulan 5216 sayılı Büyükşehir Belediyesi Kanunu’nun 7. maddesi ${ }^{4}$ büyükşehir belediyelerinin görevleri arasında engelli hizmetlerini de saymıştır. 5393 sayılı Belediye yasasında olduğu gibi 5216 sayılı yasanın 18. maddesi de büyükşehir belediye başkanına engellilerle ilgili faaliyetlere destek olmak amaciyla engelli merkezi kurma görevi vermiştir. Ayrıca büyükşehir belediyesinin engelliler için yaptığı sosyal hizmet ve yardımların da belediyenin giderleri arasında olduğu 5216 sayılı yasanın 24 . maddesiyle hüküm altına alınmıştır.

5216 sayılı kanuna, 5378 sayılı Engelliler Hakkında Kanun ile eklenen geçici 1. madde ${ }^{5}$ ile büyükşehir belediyelerine engelli hizmet birimlerini kurma zorunluluğu getirilmiştir. Böylece büyükşehir belediyelerinin teşkilat yapısında engelli hizmet birimlerine de daimi olarak yer verilmiştir. Engelli hizmet birimleri faaliyet alanları ile ilgili olarak engellilere yönelik kurulmuş vakıf ve dernekler ile bunların üst kuruluşlarıyla işbirliğine gidebilmektedir. Ayrıca 5216 sayılı kanunun 7. maddesi gereğince ilçe belediyelerinin görev ve yetkileri arasında engellilere yönelik sosyal ve kültürel hizmetler sunmak ve mesleki eğitim ve beceri kursları açmak da yer almıştır.

Büyükşehir belediyelerinin teşkilat yapısında yer alan Engelli Hizmet Birimlerinin görev, yetki ve sorumlulukları ile işleyişine dair 16.08.2006 tarihinde "Büyükşsehir Belediyeleri Engelli Hizmet Birimleri Yönetmeliği” yayınlanmıştır. Fakat Devlet Denetleme Kurulu'nun 2009 yılında yayımladığı raporda yönetmeliğin diğer belediyeler ile il özel idareleri için de bir rehber olduğu belirtilmiştir (Onur İnce vd., 2016: 88). Dolayısıyla büyükşehir belediyeleri dişındaki diğer yerel yönetim birimleri içinde engelli hizmetlerinde yönlendirici bir yönetmelik ortaya çımıştır.

\section{MALATYA BÜYÜKŞEHIR BELEDIYYESINİN ENGELLILERE YÖNELİK HİZMETLERİ}

Büyükşsehir belediyeleri başta olmak üzere birçok belediye bünyesinde kurulan engellilere yönelik hizmet birimleri aracıllı̆ıylaengelliklere yönelik çeşitli görev ve sorumluluklar yerine getirilmektedir. Bu belediyeler arasındaki büyükşsehirlerden birisi de Malatya Büyükşehir Belediyesi'dir.

2012 yılında yerel yönetim alanında yapılan yasal düzenlemeler sonucunda belediyeler ile diğer yerel yönetim birimlerinde önemli değişiklikler yapılmıştır. 12 Kasım 2012'de kabul edilerek 6 Aralık 2012'de resmî gazetede yayınlanan "6360 sayılı On Dört İlde Büyükşehir Belediyesi ve Yirmi Yedi İlçe Kurulması ile Bazı Kanun ve Kanun Hükmünde Kararnamelerde Değişiklik Yapılmasına Dair Kanun” ile yerel yönetim

\footnotetext{
${ }^{4}$ Yasanın 7. maddesinin v bendinde "Sağlık merkezleri, hastaneler, gezici sağlık üniteleri ile yetişkinler, yaşlılar, engelliler, kadınlar, gençler ve çocuklara yönelik her türlü sosyal ve kültürel hizmetleri yürütmek, geliştirmek ve bu amaçla sosyal tesisler kurmak, meslek ve beceri kazandırma kursları açmak, işletmek veya işlettirmek, bu hizmetleri yürütürken üniversiteler, yüksek okullar, meslek liseleri, kamu kuruluşları ve sivil toplum örgütleri ile işbirliği yapmak." hükmü getirilerek engelli hizmetlerinde büyükşehir belediyelerine sorumluluk verilmiştir.

${ }^{5}$ Ek Madde 1- (Ek: 1/7/2005-5378/40 md.) : "Büyükşehir belediyelerinde engellilerle ilgili bilgilendirme, bilinçlendirme, yönlendirme, danışmanlık, sosyal ve mesleki rehabilitasyon hizmetleri vermek üzere engelli hizmet birimleri oluşturulur. Bu birimler, faaliyetlerini engellilere hizmet amaciyla kurulmuş vakıf, dernek ve bunların üst kuruluşlarıyla işbirliği hâlinde sürdürürler. Engelli hizmet birimlerinin kuruluş, görev, yetki, sorumluluk ve işleyişine ilişkin usûl ve esaslar Özürlüler İdaresi Başkanlığının görüşü alınarak Çevre ve Şehircilik Bakanlığınca hazırlanacak yönetmelikle belirlenir."
} 
ve özellikle de büyükş̧ehir yönetim sisteminde önemli değişiklikler yapılmıştır. 30 Mart 2014 Yerel Seçimleri ile birlikte uygulamaya başlanılan 6360 sayılı yasa gereğince 14 il belediyesi, büyükşehir belediyesi yapılmış ve bu belediyelerinin sınırları, il mülkî sınırlarına kadar genişletilmiştir. Bu belediyelerden birisi de Malatya Belediyesi'dir. Yasa ile birlikte büyükşehir belediye yönetim şekline dönüşen Malatya Belediyesi'nin hizmet alanı ile sorumlulukları da artmıştır.

Malatya Büyükşehir Belediyesi (MBB) teşkilat yapısı içerisindeki Kültür ve Sosyal İşler Dairesi Başkanlığı bünyesinde çeşitli sosyal hizmet ve yardımlar yürütülmektedir. Dolayısıyla bu daire başkanlığı bünyesinde kurulmuş olan Engelliler ve Yaşlı Hizmetleri Şube Müdürlüğü tarafindan engelli hizmetleri sunulmaktadır (MBB Organizasyon Şeması, 2019). Ayrıca belediye bünyesindeki bir diğer daire başkanlığı olan Sağlık ve Sosyal Hizmetler Dairesi Başkanlı̆̆ tarafından da sosyal yardım ve hizmet, sağlık gibi alanlarda çeşitli hizmetler sunulmaktadır (MBB 2018 Yılı Faaliyet Raporu, 2019: 473).

\subsection{Bakım ve Destek Hizmetleri}

Malatya Büyükşehir Belediyesi tarafından kent bütününde yaşayan engelli bireylere yönelik bakım, yardım, sağlık gibi konularda bakım ve destek hizmetleri sunulmaktadır. Büyükşehir belediyesi 2015 yılından itibaren engelli, yaşlı ve ihtiyaç sahibi kişilere yönelik evde bakım hizmeti kapsamında "Yalnız Değilsiniz" projesini başlatmıştır. Proje kapsamında engelli veya yaşlı kimseler yaşam alanlarında ziyaret edilerek ihtiyaçları tespit edilmiştir. Daha sonra Malatya İl Sosyal Yardımlaşma ve Dayanışma Vakfı ile işbirliğine gidilerek tespit edilen ihtiyaç ve bakımların karşılanması gerçekleştirilmiştir (MBB 2015 Yılı Faaliyet Raporu, 2016: 329).

Sağlık ve Sosyal Hizmetler Dairesi Başkanlığı'na bağlı Sağlık İşleri Şube Müdürlüğü; engelli, yaşlı ve diğer ihtiyaç sahibi kişilere ücretsiz sağlık bakımı hizmeti sunmaktadır. Müdürlük bünyesinde kurulan Sağlık Poliklinikliğinde ücretsiz muayene, diş çekimi, pansuman, enjeksiyon gibi sağlık hizmetleri ile reçeteli ihtiyaç sahibi kişilere ücretsiz ilaç yardımı yapılmaktadır (MBB 2016 Yılı Faaliyet Raporu, 2017: 345).Belediyeye yardım talebinde bulunan ihtiyaç sahipleriyle ilgili tahkikat yapılarak muhtaçlık derecesine ve nüfuslarına göre gıda, ekmek, nakdi, yol vb. çeşitli yardımlar yapılmaktadır. Bu bağlamda MBB; İl Sosyal Yardımlaşma ve Dayanışma Vakfı, İlçe Belediyeleri, Engelliler Merkezi gibi çeşitli kurumlarla işbirliği yaparak engelli, yoksul, yaşlı gibi mağdurların tespitlerinin yapılması ve yaşam standartlarının iyileştirilmesini temel amaç edinmiştir. Bu bağlamda büyükşehir belediyesinin 2016 yılında yardım yaptığ kişi sayısı 118.525'e ulaşmıştır (MBB 2016 Y1lı Faaliyet Raporu, 2017: 346-349). Dolayısıyla belediyelerin merkezi idarenin yereldeki hizmetlerine destek ve katkı sunması önem arz etmektedir.

2016 y1lında Malatya Büyükşehir Belediyesi, engelli bireylerin kimlik ve adres ile engellilik ve sosyoekonomik durum bilgilerinin yer aldığı Engelli Kayıt Sistemi'ni kurarak engellilere yönelik bilgi veri tabanı oluşturmuştur. Böylece, veri sistemine kaydı yapılan 1.700 engelli bireye belediyenin hizmetleri ve yürüttüğ̈̈ faaliyetler hakkında bilgilendirme işlemi başlatılmıştır. Ayrıca zihinsel ve işitsel yönden engelliler için özel sınıflar oluşturularak 300 engelli bireye Engelli Kamu Personeli Seçme Sınavı'na yönelik eğitim hizmeti verilmiştir. Böylece 50 engelli bireyin kamusal alanda memur olarak istihdam edilmesi sağlanmıştır (MBB 2016 Y1lı Faaliyet Raporu, 2017: 357). Bu bakımdan belediyeler istihdam konusunda özel gereksinim duyan dezavantajlı gruplara yönelik imkân ve firsat sunulması konusunda sorumluluk üstlenme ve yetki paylaşma fonksiyonlarına sahip olmaktadır.

Büyükşehir Belediyesi engelli bireylere yönelik eğitim, istihdam gibi hizmetler yanında danışmanlık ve rehberlik hizmetlerine de önem vererek bu alanda hizmetlerini arttırmaya başlamıştır. Bu çerçevede Engelli Koordinasyon Şube Müdürlüğü bünyesinde Kamu Personeli Seçme Sınavı'na yönelik 200 engelli aday ile 800 den fazla engelli bireye engellilik ve sorunları hakkında çeşitli konularda danışmanlık ve rehberlik hizmeti sunulmuştur. Bu hizmetlerin yanı sıra ulaşım konusunda engelli bireylere destek olmak için bir başka çalışmayı da başlatmıştır. Bu konuda görme, ortopedik ve ağır zihinsel engelli bireylerin gidecekleri yerlere daha rahat ve konforlu şekilde ulaşabilmelerini sağlamak amaciyla, randevulu sistemle çalışan ve özel olarak hazırlanmış engelli aracı engellilerin hizmetine sunmuştur. Ayrıca bu bireylerin ihtiyaçlarına yönelik tekerlekli sandalye, yürüteç, koltuk değneği gibi çeşitli türde medikal malzeme yardımı yapılmıştır (MBB 2016 Y1l1 Faaliyet Raporu, 2017: 358-360).

Toplumda sağlıklı ve normal bir birey kadar engelli bireyin de yer alabilmesinin yöntemlerinden birisi de toplumsal bilincin artırılması ve duyarlılığın geliştirilmesidir. Bu bağlamda Malatya Büyükşehir Belediyesi 3 Aralık Dünya Engelliler Gününde, engelli ve sorunlara yönelik farkındalık oluşturma ve toplumu bilgilendirme amacıyla kentin muhtelif yerlerindeki tanıtım yerlerine engellilik ile ilgili görsel ve yazılı bildiriler asmıştır. Ayrıca Dünya Engelliler Gününde engelliler ile yakınlarına özel bir program hazırlanarak engellilerin ürettiği el ürünlerinin sergi ve tanıtımı yapılmıştır (MBB 2016 Yılı Faaliyet Raporu, 2017: 359). 
Dolayısıyla engellilerin hem toplumsal hayata tutunmalarına hem de toplumsal bilincin artmasina, düzenlenen bu tür faaliyetlerle büyükşehir belediyesi katkı vermiştir.

Engelli bireylerin sağlıklı bir yaşama kavuşmalarına destek olmayı hedefleyen büyükşehir belediyesi çeşitli sağlık hizmetlerini engelli bireylere sunmaya çalışmıştır. Bu amaçla işitme engelli doksan bireyin işitme yönlü sağlık testi taraması yapılarak tedavileri konusunda yardım, danışmanlık ve yönlendirme hizmeti sunulmuştur. Ayrıca hem yaşadıkları çevreye hem de toplum hayatına hızlı ve sağlıklı bir şekilde uyum sağlamalarına katkı vermek amacıyla ihtiyaç sahibi iki yüz on üç engelli bireye tekerlekli sandalye ile çeşitli türde medikal malzeme yardımı yapılmıştır. Bunların yanı sıra toplam altı yüz otuz engelli bireye de taşıma ve ulaşım hizmeti Malatya Büyükşehir Belediyesi tarafindan 2017 yılı içerisinde sunulmuştur (MBB 2017 Yılı Faaliyet Raporu, 2018: 475-476). Bu bakımdan engellilere yönelik koruyucu ve destek hizmetleri konusunda belediyeler yerel alanlarda daha güçlü olabilmektedir.

Sağlıklı bireyler gibi sosyal hayatta engelli bireylerinde güvenli ve kolay ulaşım sağlayabilmeleri için cadde ve sokakların yeniden düzenlenmesi yapılmıştır. $\mathrm{Bu}$ amaçla engellilerin yaya geçitleri ile cadde ve sokakları bulması ve güvenli bir şekilde ulaşım yapabilmeleri amacıyla cadde, konum, trafik 1şıkları gibi durumlar hakkında titreşimli, sesli ve Braille alfabesi ile bilgi sunan akıllı buton sistemleri çeşitli cadde ve kavşaklara kurulmuştur (MBB 2016 Yılı Faaliyet Raporu, 2017: 414). Ayrıca engelli rampası, sarı çizgi, izli-yol uyarı uygulamaları (MBB 2016 Y1lı Faaliyet Raporu, 2017: 212-213) ile yaya üst geçitleri ile diğer trafik ulaşım kanallarına engelli asansörü ve rampa hizmeti çalışmaları (MBB 2018 Y1lı Faaliyet Raporu, 2019: 282) büyükşehir belediyesi tarafindan engelli bireylere sunulan diğer hizmetler arasındadır. Sosyal destek konusunda engellilere yönelik yasal sorumluluklarını yerine getiren belediyeler, aynı zamanda merkezi idarenin tamamlayıcı ve destekleyici rolünü de gerçekleştirmektedir.

\subsection{Sosyal, Kültürel ve Eğitim Hizmetleri}

Büyükşehir belediyesi düzenlediği kurs ve eğitimlerle engelli bireylerin hem sosyalleşmelerini hem de toplum hayatına adaptasyonlarını sağlamayı hedeflemiştir. Bu bağlamda 2015 yılında Engelliler Koordinasyon Şube Müdürlüğü tarafından çeşitli eğitim ve danışmanlık hizmetleri sunulmuştur. Başta zihinsel engelli bireyler olmak üzere çeşitli türdeki engelli bireylere yönelik Halk Eğitim Müdürlüğü ile iş birliği yapılarak Osmanlı Minyatür Kursu ile Çeyiz Hazırlama Kursu düzenlenmiştir (MBB 2015 Y1lı Faaliyet Raporu, 2016: 337-338).

Malatya Büyükşehir Belediyesi, engelli bireylerin istihdamı konusunda yardımcı olmak için 2015 yılında Engelli Kamu Personeli Seçme Sınavı kursu vermiştir. Kurs kapsamında işitme, görme, zihinsel ve genel engellilik durumları ile lise, ön lisans ve lisans mezunu seviyelerine göre ayrı ders ortamı ile sınıfları oluşturularak 300 kişi sınava hazırlanmıştır. Ayrıca kura ve tercih dönemlerinde bu engelli bireylere danışmanlık hizmetleri de sunulmuştur. Böylece kursa katılan engelli bireylerden yarıya yakını memur olarak kamu kurumlarına atanmıştır (MBB 2015 Yılı Faaliyet Raporu, 2016: 338-339). Dolayısıyla engelli bireylere sunulan eğitim hizmeti sonucunda engelli bireylerin istihdam edilmesi sağlanmıştır.

Engellilerin sosyal ve kültürel alanda da yer alabilmesini hedefleyen büyükşehir belediyesi spor kulübüne verilen destekle engelliler sportif faaliyetlere katılma imkânı bulmuştur. 2015 yılında Türkiye Bedensel Engelliler Kupası müsabakasına katılan altı engelli sporcu altın, gümüş ve bronz madalyalar kazanmıştır. Bunların yanı sıra yüz engelli birey ile ailelerine yönelik Aile ve Sosyal Politikalar İl Müdürlüğü ile ortak program kapsamında engelli hakları ile obezite ve sağlıklı yaşam konularında seminerler verilmiştir. Ayrıca Büyükşehir Belediyesi tarafından ilk kez Malatya'da düzenlenen Engelsiz yaşam Fuarı kapsamında engellilere yönelik faaliyet gösteren sivil toplum kuruluşları, kamu kurumları, medikaller ile özel eğitim veren kuruluşların fuara katılımları sağlanarak stantlar açtııılmıştır. Fuar kapsamında seminerler, resim sergileri, özel sektörün sahne gösterileri gibi engelli ve engellilik konusunda bilgilendirme ve bilinçlendirme çalışmaları yapılmıştır (MBB 2015 Y11ı Faaliyet Raporu, 2016: 338). Böylece toplumun engelliler konusunda bilgi ve bilinç düzeyleri arttırılarak, engelli bireyler ile ailelerinin ihtiyaç ve beklentilerine dikkat çekilmiştir.

Sanatsal ve kültürel değerlerin yaşatılması ve gelecek nesillere aktarılması amaciyla Sanat Etkinlikleri Şube Müdürlüğü bünyesinde 2016 y1lında çeşitli branşlarda kurs ve eğitimler verilmiştir. Bu amaçla sunulan eğitim faaliyetlerine büyükşehir belediyesi engelli bireyleri de dâhil ederek engellilerin sosyal hayattaki varlıkları daha da güçlendirilmeye çalışılmıştır. Bu çerçevede çini, kil şekillendirme, karakalem, yağlı boya, temel sanat eğitimi, grafik tasarım, fotoğrafçılık, diksiyon, drama, keman, piyano, gitar, tiyatro alanlarında 31 engelli bireye eğitim kursu açmıştır(MBB 2016 Yılı Faaliyet Raporu, 2017: 315). Böylece kültür ve sanat alanlarında ulusal ve uluslararası düzeyde kabul görecek şekilde ulusal veya yerel kültür ve sanatın tanıtımının yapılıp yaşatılmasına engelli bireylerin de katkı yapabilmesinin yolu açılmıştır. 
Kültür ve eğitim alanlarının yanı sıra spor alanında da engelli bireylerin daha fazla yer alması ve spora teşvik amaçlı engelli bireyler için Büyükşehir Belediyesi tarafından özel spor merkezi kurulmuştur. Ayrıca diş hastanesi ile birlikte yürütülen bir proje ile engelli bireylerin ağız ve diş sağlığı taraması başlatılmış ve sağl1kla ilgili bilgilendirme ve yönlendirme hizmetleri sunulmuştur (MBB 2016 Y1lı Faaliyet Raporu, 2017: 358-359). Malatya Büyükşehir Belediyesi hem engelli bireyin eğitimine katkı vermek hem de engellinin sosyal çevresiyle uyumun sağlanabilmesi amaciyla çeşitli konu ve alanlarda eğitim ve kurslar düzenlemeye başlamıştır. $\mathrm{Bu}$ çerçevede belediyenin birimlerinde çalışan personele işaret dili, engelli hakları gibi konularda hizmet içi eğitimler vermiştir. Ayrıca engelli bireylere yönelik girişimcilik ile dart, ev tekstili, bilgisayar işletmenliği gibi farklı alanlarda çeşitli eğitim ve kurslar düzenlenmiştir (MBB 2016 Yılı Faaliyet Raporu, 2017: 360-364). Dolayisıyla engelli bireyin sosyal ve ekonomik hayata tutunma konusundaki mücadelesine belediyeler kişisel gelişim yönünden destek vererek katkı sunmayı amaçlamıştır.

Kültürel ve eğitim konularında engelli bireylerin gelişmesine önem veren Malatya Büyükşsehir Belediyesi 2016 yılında başlattığı kültürel çalışmalarına devam etmiş ve 2017 yılında Sanat Etkinlikleri Şube Müdürlüğü bünyesinde keman, piyano, gitar, karakalem, drama gibi kültürel alanlarda 38 engelli bireye eğitim ve kurslar düzenlemiş̧tir (MBB 2017 Yılı Faaliyet Raporu, 2018: 433). Ayrıca engelli bireylerin ulaşım konularına yardımcı olmak için kendi sunduğu hizmetler dışında sivil toplum kuruluşlarına da destek vermiştir. Bu kapsamda engelli öğrencilerin eğitim hayatlarına devamı için ihtiyaç duydukları konforlu ulaşım konusunda faaliyet yürüten bir sivil toplum kuruluşuna destek vererek nakdi yardımlarda bulunmuştur (MBB 2017 Yılı Faaliyet Raporu, 2018: 469). Nitekim engelli bireylerin eğitim konusunda Malatya Büyükşehir Belediyesi'nin hizmetlerinden olan Engelli Kamu Personeli Seçme Sınavı hazırlık kursu ile 2010-2017 yılları arasında kamusal alanda istihdam amaçlı üç yüz elli engelli birey memur olarak atanmıştır (MBB 2017 Yılı Faaliyet Raporu, 2018: 474). Böylece büyükşehir belediyesi bu tür hizmetleriyle engellilerin hem istihdamı hem de eğitim ve kültür yönüyle engeli bireylere doğrudan firsat sağlamıştır.

Engelli bireylerin toplum hayatına uyumlarının kolaylaştırılması ve karşılaştıkları kente özgü sorunların çözüme kavuşturulması amacıyla Malatya Büyükşehir Belediyesi engellilerle doğrudan iletişim ve etkileşim süreci başlatmıştır. Bu kapsamda büyükşehir belediyesi engellilere yönelik çalışan sivil toplum kuruluşlarıyla birlikte farklı türdeki engelli bireylerin katıldığı çeşitli istişare ve söyleşi toplantıları düzenlemiştir. Ayrıca engellilerin hem toplum hayatındaki varlıklarına dikkat çekmek hem de onların toplum hayatına adapte olmalarına destek olmak için engelli eğitmenler tarafından on bir okuldaki öğrencilere engellilik ve engelli birey konularında seminerler verilmiştir (MBB 2017 Y1lı Faaliyet Raporu, 2018: 477).

Toplum hayatında engelli bireylerin varlığına dikkat çekmek için Malatya Büyükşehir Belediyesi faaliyetlerine devam etmiştir. Bu bağlamda engelli bireylerle ilgili farkındalık oluşturmak için sivil toplum kuruluşuyla işbirliği yaparak otizmli bireyler ile diğer engelli birey ve aileleriyle bir araya gelinerek engellilerin katıldığı spor yarışları, söyleşi ve diğer çeşitli programlar gerçekleştirmiştir. Ayrıca farkı engelli türü ve düzeyine sahip bireylerin kendi işyerlerini kurabilmeleri amacıyla iş ve meslek danışmanları tarafından destek ve hibe programları hakkında bilgilendirme ve danışmanlık hizmetleri Büyükşehir Belediyesinin düzenlediği seminerlerle sunulmuştur (MBB 2018 Yılı Faaliyet Raporu, 2019: 83).

\section{SONUÇ}

Merkezi idarenin, yerel nitelikli hizmetlerin yürütülmesindeki önemli destekleyicilerinden birisi de belediyelerdir. Bu bakımdan belediyeler, yerelde engellilere yönelik sosyal politikaların uygulanmasındaki aktörler arasında yerini almıştır. Çünkü belediyelerin engelli alanında sunduğu faaliyetler ve üstlendiği yasal görevler, bu alanda ileriye dönük yapılacak politikalarda planlama, uygulama gibi konularda belediyelere daha fazla sorumluluklar yüklenebileceği anlamına gelmektedir.

Yasal düzenlemelere bağlı olarak süreç içerisinde belediyelerin hem sosyal hizmet yönlüyetkileri hem de genişletilen hizmet alanları belediyelerin engellilik konusundaki faaliyetlerini hızlandırmıştır. Bu çerçevede genel olarak belediyelerin, özelde ise büyükşehir belediyelerinin engellilerin toplum hayatına uyumunun desteklenmesinden, eğitim ve istihdamına kadar çeşitli konularda uygulamaları görülmektedir. Çünkü belediyelerin sahip olduğu kaynakları ile bulunduğu çevre şartları engellilere yönelik hizmetin niteliğini belirlemektedir. Bu bağlamda Malatya Büyükşsehir Belediyesi'nin engellinin istihdamı konusundaki eğitim ve destek planlaması bunun bir örneğini oluşturmuştur.

Belediyelerin fonksiyonları gereği yerel halkın müşterek ihtiyaçları ile beklentilerini karşılamakla sorumlu olmaları, sosyal politikaların yürütülmesinde belediyelere doğrudan sorumluluk yüklemiştir. Dolayısıyla belediyeler; kendi sınırları içerisinde yaşayan yerel halkın refahını yükseltmek, temel insani haklara kolayca ulaşımı sağlamak ve sosyal adaleti sağlamak gibi konuları yereldesunmakla sorumlu 
tutulmuştur. Bu sorumlulukların yanı sıra belediyelerinyürütmekle yükümlü olduğu diğer gruplar arasında engelli bireyler ile onlara yönelik hizmetler de bulunmaktadır.

Engelli bireylere yönelik hizmet, kaynak ve imkânların erişebilirlik ve ulaşılabilirlik noktasında birçok belediyenin kendi sınırları içerisinde faaliyetler yürütmeye çalıştığı görülmektedir. Bu belediyelerden birisi de Malatya Büyükşehir Belediyesi’dir. 5216 sayılı Büyükşehir Belediye Yasası ile 5393 sayılı Belediye Yasası gereğince engellilere yönelik meslek veya beceri kursları açmak, sosyal yardım ve destek ile çeşitli sosyo-kültürel programları Malatya Büyükşehir Belediyesi sunmaktadır.

Büyükşehir belediyesinin, engellilerin meslek ve beceri kazanması için düzenlendiği çeşitli türdeki destek programları ile eğitim kursları en önemli hizmetleri arasında olmuştur. Çünkü bu hizmetlerin sağlanmasının sonunda engelli bireyler istihdama doğrudan katılmıştır. Böylece engelli bireylerin bağımsız olarak yaşamlarını sürdürmelerine ve sosyal yaşama katılmalarına imkân tanınmıştır.

Engellilik ve engelli sorunları hakkında bilgilenme ve bilinçlenme konularında Malatya Büyükşehir Belediyesi personelinin gelişmesi için çeşitli kurs ve programlar düzenlenmiştir. Bununla birlikte engellilerin ve ailelerinin karşılaştıkları sorunları kendi başlarına çözebilmeleri için kapasite geliştirici eğitimler verilmiştir. Ayrıca engellilerin beden ve ruh sağlığına destek olmak için spor alanında tesis kurma, turnuvalar düzenleme gibi çeşitli projeleri hayata geçirilmiştir.

Büyükşehir belediyeleri ile diğer belediyelerin engellilere yönelik yaptığı hizmet ve çalışmalar oldukça çeşitlenmiştir. $\mathrm{Bu}$ hizmetlerle, merkezi yönetimin engellilere yönelik sosyal politika uygulamalarında, büyükşsehir belediyeleri önemli destekçi olmuştur. Ancak engelli konusundaki hizmetlerde büyükşehir belediyeleri dışındaki diğer belediyelerin sunduğu hizmetler, sosyal yardım, fiziki mekânların iyileştirilmesi ve çeşitli sosyal yardım programları ile sınırlı kalmıştır. Bu nedenle engelli hizmetleri konusunda üniversiteler, sivil toplum kuruluşları, mesleki kurum ve kuruluşlar, özel sektör gibi yerel paydaşlarla belediyeler işbirliği yaparak hizmetlerin niteliğini geliştirmelidir.

Belediyelere, engellilere yönelik verilen yasal görev ve sorumluluklarla eşdeğer olacak şekildemerkezi idaretarafından insan ve finans kaynağı desteğinin arttırılması bu alandaki hizmetlerin niteliğinin gelişmesine imkân verecektir. Ayrıca belediyeler engelli konusunda kurum kültürü ile yerel halkın bilincini arttıracak plan ve projelerini stratejik hedefleri arasına koymalıdır. Yerel idare olarak büyükşehir belediyeleri ile diğer belediyeler kendi aralarındaki koordinasyonu güçlendirmeli ve engelli alanındaki başarılı hizmet uygulamaları ile tecrübe paylaşımını daha fazla yapmalıdır. 


\section{KAYNAKÇA}

Arıkan, Ç. (2001). Türkiye'de Görme Özürlü Kadınlar: Sorunlar, Beklentiler, Çözüm Önerileri. Körler Federasyonu Yayınları No: 3, Ankara.

Artan, T. (2012). Yerel Yönetimlerde Sosyal Hizmetler. Sabev Yayınları, Ekim, Ankara.

Balcı, S. (2013). Osmanlı Devleti’nde Engelliler ve Engelli Eğitimi Sağır Dilsiz ve Körler Mektebi. Libra Yayıncılık. İstanbul.

Birleşmiş Milletler Engelli Hakları Sözleşmesi, https://humanrightscenter.bilgi.edu.tr/media/uploads/2015/08/03/EngellilerinHaklarinalliskinSozles me.pdfErişim Tarihi: 18.07.2019

Çarkçı, Ș. (2011). Engellilerin Mesleki Eğitimi ve İstihdamı, Yüksek Lisans Tezi, Marmara Üniversitesi Sosyal Bilimler Enstitüsü, İstanbul.

Çetin, I. B. (2016). “Antik Çağ’dan Sanayi Devrimi’ne Batı Dünyasında Engellilik Tarihi”. Balıkesir Üniversitesi Sosyal Bilimler Enstitüsü Dergisi, 19 (36-1), İ̈BF - 10. Yı1 Özel Sayıs1, s. 167-185

Çetin, I. B. (2017). "Sanayi Devrimi'nden 21. Yüzyıla Batı Dünyasında Engellilik”. Sosyal Güvenlik Dergisi, 7 (1), s. 91-121.

Danış, M. Z. (2005). Toplum Temelli Bakım Anlayışı. Özveri Dergisi, 2 (1), s. 50-59. https://www.ailevecalisma.gov.tr/media/2627/3sayi-2005-cilt-2sayi-1.pdf Erişim Tarihi: 21.07.2019

Dünya Engelliler Vakfi (2018). Engelsiz Șehir Tasarım Raporu. http://www.devturkiye.org/Projeler/Engelsiz Sehir-Planlamasi/Engelsiz-Sehir-Tasarim-Raporu/ Erişim Tarihi: 19.07.2019

Firat, A. S. (2008). "Belediyelerin Engellilere Dönük Sosyal Hizmet Projeleri”. Toplum ve Sosyal Hizmet Dergisi, 19 (1), s. 89-100.

Genç, Y. (2015).“Engellilerin Sosyal Sorunları ve Beklentileri”. Sosyal Politika Çalı̧maları Dergisi, 15 (35/2), s. 65-92.

Genç, Y. ve Barış, İ. (2015). "Sosyal Hizmetlerin Yeniden Yapılandırılmasında Yerinden Yönetimin İşlevselliğı". TheJournal of AcademicSocialScienceStudies (JASS), 32, pp. 95-117.

Genç, Y. ve Çat, G. (2013). "Engellilerin İstihdamı Ve Sosyal İçerme İlişkisi”". Sakarya Üniversitesi Sosyal Bilimler Enstitüsü Akademik İncelemeler Dergisi (Journal of AcademicInquiries), 8 (1), s. 363-393.

Genç, Y. (2009). "Yerel Yönetimler ve Sosyal Hizmet Uygulamaları". Kamuda Sosyal Politika Dergisi, 3 (9), s. 60-67.

Gökmen, F. (2007). “Türkiye’de Özürlü Haklarının Gelişimi”, Özveri Dergisi, T.C. Başbakanlık Özürlüler İdaresi Başkanlığ 1,4 (2), s. 1085-1106.

Kalaycı, S. (2017). "Belediyelerin Sosyal Hizmetlerin Sunumuna Yönelik Yasal Sorumlulukları". International Journalof Academic Value Studies, 3 (10), pp: 124-129.

Karataş, K. (2001). "Belediyelerin Sosyal Görevleri: Belediyeler ve Sosyal Hizmetler". İnsani Gelişme ve Sosyal Hizmet: Prof. Dr. Nesrin Koşar'a Armağan, Ed.: Kasım Karataş ve Çiğdem Arıkan, s. 214-226, Hacettepe Üniversitesi Sosyal Hizmetler Yüksekokulu Yayını No: 009, Ankara.

Kesgin, B. (2016). "Sosyal Hizmetin Yerelleşmesi Ve Sosyal Hizmette Yerel Yönetimlerin Artan Rolü”. MCBÜ Sosyal Bilimler Dergisi, 14 (4), s. 319-340.

Kesgin, B. (2015). "Etkinlikle Verimlilik Arasında Belediyeler". Uluslararası İktisadi ve İdari İncelemeler Dergisi, 14, s. $157-176$.

Kesgin, B. (2014). “Engellilere Yönelik Yerel Sosyal Politikalar”. Çağdaş Yerel Yönetimler Dergisi, 23 (4) Ekim, s. 115.

Kesgin, B. (2012). Kamu Sorumluluğunda Sosyal Hizmet. Açılım Kitap, İstanbul.

Kolat, S. (2009). Avrupa Birliği Sosyal Politikası Çerçevesinde Özürlülere Yönelik Ayrımcılıkla Mücadele ve Türkiye'deki Yansımaları, Yayınlanmış Uzmanlık Tezi, T.C. Başbakanlık, Ankara.

Köse, H. (2014). Kronolojik Engelli Tarihi ve Eğitimi. Engelliler Eğitiminin Tarihsel Gelişimi, İstanbul: İstanbul MEB Yayınlar1. s. 56-100.

Küçükali, A. (2015). "Engellilere Uygulanan Sosyal Yardımlar”. Sosyal ve Beşeri Bilimler Araştırmaları Dergisi, 16 (35), s. 100-115.

Malatya Büyükşehir Belediyesi (MBB) 2014 Yılı Faaliyet Raporu. (2015). http://www.malatya.bel.tr/yayin/2014_faaliyet_raporu/files/assets/basic-html/index.html\#1 Erişim Tarihi: 17.07.2019

Malatya Büyükşehir Belediyesi (MBB) 2015 Yllı Faaliyet Raporu. (2016). http://www.malatya.bel.tr/yayin/2015_faaliyet_raporu/files/assets/basic-html/index.html\#1 Erişim Tarihi: 17.07.2019

Malatya Büyükşehir Belediyesi (MBB) $2016 \quad$ Yılı Faaliyet Raporu. http://www.malatya.bel.tr/yayin/2016_faaliyet_raporu/files/assets/basic-html/index.html\#1Erişim Tarihi: 17.07.2019

Malatya Büyükşehir Belediyesi (MBB) 2017 Yılı Faaliyet Raporu. (2018).

http://www.malatya.bel.tr/yayin/2017_faaliyet_raporu/files/assets/basic-html/index.html\#1 Erişim Tarihi: 17.07 .2019 
Malatya Büyükşehir Belediyesi (MBB) $2018 \quad$ Y1lı Faaliyet Raporu. (2019). http://www.malatya.bel.tr/yayin/2018_faaliyet_raporu/faaliyet_raporu_2018.pdf Erişim Tarihi: 17.07.2019

Malatya Büyükşehir Belediyesi (MBB) Organizasyon Şemas1 (2019). http://www.malatya.bel.tr/organization/11/0/organization.aspx Erişim Tarihi: 21.07.2019

Onur İnce, H., Babaoğlu, C. ve Yaralı Akkaya, A. (2016). "Belediye Hizmetleri ve Engelli Vatandaşların Beklentileri Üzerine Ampirik Bir Araştırma". Nevşehir Hacı Bektaş Veli Üniversitesi Sosyal Bilimler Enstitüsü Dergisi, 6 (2), s.86-109.

Öktem, M. K. (2006). "Kamu Yönetimi Tartışması Bağlamında Sosyal Hizmetler”. Toplum ve Sosyal Hizmet Dergisi, 17 (2), s. 41-55.

Önen, S. M. (2010). "Yerel Yönetimlerin Yoksullukla Mücadelesi: Malatya Belediyesi Örneği”. Sayıştay Dergisi, Ekim - Aralik, 79, s. 63-95.

Öztürk, M. (2011), “Türkiye’de Engelli Gerçeği”, Editör: Abdullah Serenli, MUSİAD Cep Kitapları: 30, İstanbul.

Şensoy, N. ve Karabekir, H. S. (2011). "Evde Bakım: Olgu Serisi”. Geriatri ve Geriatrik Nöropsikiyatri Dergisi, 2 (2-3), s. 21-27.

Tekeli, İ. (1983). "Yerel Yönetimlerde Demokrasi ve Türkiye’de Belediyelerin Gelişimi”. Amme İdaresi Dergisi, 16 (2), s. 3-22.

World HealthOrganization -WHO- (2011). World Report on Disability, Malta. https://www.who.int/disabilities/world_report/2011/en/ Erişim Tarihi: 19.07.2019

"Yaşlı Dostu Belediye".(2019). https://www.ankara.bel.tr/haberler/yasli-dostu-belediye/ Erişim Tarihi: 21.07 .2019 1982 Anayasas1.

5216 sayılı Büyükşehir Belediye Kanunu.

5378 sayılı Engelliler Hakkında Kanun.

5393 sayılı Belediye Kanunu.

26261 sayılı ve 16.08.2006 tarihli Resmi Gazete: Büyükşehir Belediyeleri Engelli Hizmet Birimleri Yönetmeliği. http://malatyahaber.com/haber/yasli-ve-engelliler-icin-asansor/ Erişim Tarihi: 19.07.2019

http://www.malatyaengelliler.org/buyuksehir-belediyesi-engelsiz-yasam-merkezi-1-etabi-tamamlandi/ Erişim Tarihi:19.07.2019

https://engellilerdostu.com/engelliligin-dunyadaki-tarihsel-gelisimi/Erişim Tarihi: 15.07.2019

https://rayhaber.com/2018/12/malatyada-ustgecitlere-engelli-ve-yaslilar-icin-asansor-yapiliyor/Erişim Tarihi: 19.07.2019

https://www.ailevecalisma.gov.tr/eyhgm/mevzuat/uluslararasi-mevzuat/ Erişim Tarihi: 19.07.2019 